PART I. PHYSICAL ACTIVITY OF SOCIAL AND PROFESSIONAL GROUPS DZIAŁ I. AKTYWNOŚĆ FIZYCZNA GRUP SPOŁECZNYCH I ZAWODOWYCH

\title{
GLOBAL PHYSICAL ACTIVITY QUESTIONNAIRE (GPAQ) - THE POLISH VERSION
}

\section{GLOBALNY KWESTIONARIUSZ AKTYWNOŚCI FIZYCZNEJ (GPAQ) - WERSJA POLSKA}

\author{
Józef Bergier $^{1(\mathrm{~A}, \mathrm{~B}, \mathrm{D}, \mathrm{E}, \mathrm{F}, \mathrm{G})}$, Małgorzata Wasilewska ${ }^{1(\mathrm{~A}, \mathrm{~B}, \mathrm{E})}$, Adam Szepeluk $^{1(\mathrm{C}, \mathrm{D}, \mathrm{E})}$
}

${ }^{1}$ Pope John Paul II State School of Higher Education in Biała Podlaska, Poland

Authors' contribution Wkład autorów:

A. Study design/planning zaplanowanie badań B. Data collection/entry zebranie danych C. Data analysis/statistics dane - analiza i statystyki D. Data interpretation interpretacja danych E. Preparation of manuscript przygotowanie artykułu F. Literature analysis/search wyszukiwanie $\mathrm{i}$ analiza literatury G. Funds collection zebranie funduszy

Tables: 1

Figures: 0

References: 11

Submitted: 2018 Jul 13

Accepted: 2018 Nov 27

\section{Summary}

The increasingly appreciated role of physical activity in societies concerned about their health requires proper assessment. The main tools for measuring the level of physical activity comprise some relevant questionnaires, among which the best known in the foreign literature is Global Physical Activity Questionnaire (GPAQ). However, this questionnaire is not yet available in the Polish language version. The following article presents one such attempt that has taken into account the Polish conditions and lifestyle following the guidelines of the GPAQ Guide, which meets the recommendations of the World Health Organization (WHO). The source text was translated into Polish and then a reverse translation was made involving four steps.

Keywords: GPAQ, the Polish version, physical activity

\section{Streszczenie}

Powszechnie doceniana rola aktywności fizycznej społeczeństw w trosce o ich zdrowie wymaga odpowiedniej oceny. Głównymi narzędziami do pomiaru poziomu aktywności fizycznej sa nadal odpowiednie kwestionariusze. Swoje miejsce w literaturze zagranicznej posiada Globalny Kwestionariusz Aktywności Fizycznej (GPAQ). Kwestionariusz ten nie jest dotychczas dostępny w wersji polskojęzycznej. Takiego opracowania dokonano w niniejszym artykule, zgodnie z zaleceniami Światowej Organizacji Zdrowia (WHO), uwzględniając dostosowanie do warunków polskich i stylu życia, zgodnie z wytycznymi Przewodnika GPAQ. Tekst źródłowy przetłumaczono na język polski, a następnie dokonano tłumaczenia zwrotnego z uwzględnieniem czterech kroków postępowania.

Słowa kluczowe: GPAQ, wersja polska, aktywność fizyczna

\section{Introduction}

The policy of increasing the level of daily, weekly and possibly all-year-round physical activity becomes a vital challenge in the care on human health at all stages of life [1]. Still, the most commonly used methodology to determine it are questionnaires, which is probably due to their high availability.

It is estimated that European residents get involved in physical activity rather irregularly [2]. Meanwhile, the optimal level of physical activity is the prerequisite for maintaining adequate health [3]. The European Commission in its questionnaire concerning health regards physical activity as one of its main determinants, as indicated by the WHO [4].

In the first period when physical activity was tested in the European Union Member States, a short
Wstęp

Polityka zwiększenia poziomu codziennej, tygodniowej i możliwie całorocznej aktywności fizycznej, staje się ważnym wyzwaniem w trosce o nasze zdrowie na wszystkich etapach (okresach) życia [1]. Z wielu sposobów jej określenia wciąż najpowszechniej stosowane są kwestionariusze, zapewne z powodu dużej dostępności do jej oceny.

Szacuje się, że duża grupa mieszkańców Europy podejmuje nieregularnie aktywność fizyczną [2]. Tymczasem warunkiem utrzymania odpowiedniego zdrowia jest optymalny poziom aktywności fizycznej [3]. Komisja Europejska w ankiecie dotyczącej zdrowia ujmuje aktywność fizyczną jako jedną z głównych determinantów zdrowia wg WHO [4]. W pierwszym okresie badania aktywności fizycznej w państwach 
version of IPAQ (the International Physical Activity Questionnaire was used - IPAQ, STEPwise Approach to Chronic Disease Risk Factor Surveillance - STEPS) [3]. Also, in Poland, the most popular questionnaires examining physical activity are the IPAQ ones, both their short and extended versions, which have been adapted to the Polish conditions in 2007 by the Biernat team [5].

Another widely-applied worldwide questionnaire examining the level of physical activity is the Global Physical Activity Questionnaire (GPAQ), still unavailable in the Polish-language version. This questionnaire was developed by the WHO in 2002 to monitor the physical activity of populations in various countries of the world [6, 7]. The GPAQ questionnaire is a synthetic combination of the short and extended versions of the IPAQ. On the one hand, unlike the short version of the questionnaire, the IPAQ concerns various domains (work-related, transportation or leisure time activities) and, on the other, unlike the extended version of IPAQ, it is much shorter, covering only 16 items in contrast to the IPAQ's 27. In addition to physical activity, the GPAQ questionnaire, like the IPAQ, also assesses the time of sitting or reclining.

The above-described questionnaire has already been used in over 100 countries, mainly under the STEPS programme. For example, the research involving the GPAQ questionnaire was conducted on the continents of Asia, Africa and America [6], as well as selected European countries [8, 9]. Initially, the GPAQ survey was developed in a way that allowed the trained personnel to conduct their study through a direct interview technique, thus including illiterate respondents. For this purpose, there had been prepared some cards with drawings illustrating different activities.

\section{Methodology}

The following article aims to present the Polish version of the GPAQ. The authors of the work have prepared the Polish version of the GPAQ following the WHO recommendations and adapting the tool to the Polish conditions and their unique lifestyle. It should be remembered that the Polish practice of having respondents fulfil the International Physical Activity Questionnaire on their own results in their overestimating the time and intensity of efforts [10]. In the GPAQ questionnaire, as in the IPAQ [11], only physical activity lasting a minimum of 10 minutes is taken into account, because only such an effort brings noticeable health benefits. On the other hand, there is an underestimation of the time spent sitting and reclining, which requires additional explanations during the research concerning, for example, time spent while sitting at work [9]. członkowskich Unii Europejskiej przeprowadzono za pomocą krótkiej wersji IPAQ (International Physical Activity Questinnaire - IPAQ, STEPwise Approach to Chronic Disease Risk Factor Survillance - STEPS) [3].

Najbardziej popularnymi kwestionariuszami badającymi aktywność fizyczną w Polsce są kwestionariusze IPAQ, zarówno krótka jak i długa wersja, które zostały dostosowane do warunków Polskich w $2007 \mathrm{r}$. przez zespół Biernat [5].

Innym popularnym na całym świecie kwestionariuszem badającym poziom aktywności fizycznej jest niedostępny do chwili obecnej w polskojęzycznej wersji Globalny Kwestionariusz Aktywności Fizycznej (GPAQ). Kwestionariusz ten został opracowany przez WHO w 2002 roku w celu monitorowania aktywności fizycznej populacji $\mathrm{w}$ różnych krajach świata [6, 7]. Kwestionariusz GPAQ stanowi syntetyczne połączenie krótkiej i długiej wersji kwestionariusza IPAQ. $\mathrm{Z}$ jednej strony, w odróżnieniu od krótkiej wersji kwestionariusza IPAQ, dotyczy różnych domen (praca, przemieszczanie się, czas wolny), natomiast w odróżnieniu od długiej wersji IPAQ jest dużo krótszy, obejmując tylko 16 pozycji, a nie tak jak IPAQ 27. Poza aktywnością fizyczną kwestionariusz GPAQ podobnie jak IPAQ ocenia również czas siedzenia lub odpoczynku w pozycji leżącej.

Omawiany kwestionariusz był wykorzystywany już w ponad 100 krajach, głównie w ramach programu STEPS. Badania przy pomocy kwestionariusza GPAQ prowadzone były na kontynentach Azji, Afryki i Ameryki [6], oraz wybranych krajach Europy [8, 9]. Początkowo kwestionariusz GPAQ został opracowany w sposób umożliwiający przeprowadzanie badania przez wyszkolony personel, techniką wywiadu bezpośredniego, również z respondentami niepiśmiennymi. Do tego celu przygotowane zostały przykłady na kartach w postaci rysunków.

\section{Metodologia}

Celem niniejszej pracy jest przygotowanie polskiej wersji GPAQ. Polska wersja GPAQ została przygotowana przez autorów tej pracy, zgodnie w zaleceniami WHO uwzględniając dostosowanie do warunków polskich i specyfiki stylu życia. Należy pamiętać, że polskie doświadczenia $\mathrm{z}$ samodzielnego wypełniania Międzynarodowego Kwestionariusza Aktywności Fizycznej wskazuje na przeszacowania czasu i intensywności wykonywanych wysiłków [10]. W kwestionariuszu GPAQ, podobnie jak w IPAQ [11], bierze się pod uwagę tylko aktywność fizyczną trwająca bez przerwy minimum 10 minut, gdyż tylko takie wysiłki przynoszą zauważalne korzyści dla zdrowia. Odnotowuje się natomiast niedoszacowanie czasu spędzanego siedząc, dlatego potrzebne są dodatkowe wyjaśnienia w trakcie badań dotyczące np. czasu spędzonego siedząc w trakcie pracy zawodowej [9]. 


\section{Adapting the GPAQ questionnaire to the Polish conditions}

The process aimed at obtaining the Polish language version of the English-language GPAQ questionnaire. The objective of the adaptation of the tool was creating a questionnaire that would not be translated literally but one regarded as a meaningful and natural survey for Poles. The source text was translated into Polish and then a reverse translation was made including the following steps:

1. Translation from English to Polish by a native speaker of Polish with a very good command of English, including knowledge of the terminology in the area covering the translation with an emphasis on conceptual translation, not a literal one.

2. A bilingual panel of experts (of English and Polish). The stage aimed at finding and correcting inappropriate expressions / concepts of the translation. The process resulted in creating a translated version of the questionnaire.

3. Reverse translation. The questionnaire was translated back into English by an independent translator whose native language is English and who has a very good knowledge of Polish. The translation discrepancies have been discussed by a bilingual panel of experts.

4. Initial tests. After the completion of the translation process, the questionnaire was used in a group of 10 people by applying a direct interview technique in order to check whether the translated terms and phrases employed in the questionnaire are understandable for the representatives of the target research group.

\section{Description of the questionnaire}

The global GPAQ activity questionnaire consists of four independent parts, containing 16 questions. The questions refer to the time devoted to physical activity lasting a minimum of 10-minute continuous effort in the respondent's typical week. The first three parts of the questionnaire concern the domains of work-related activity, transportation activity and recreational activity. In the fourth part, there is a question concerning the time spent sitting or reclining at work, at home, while moving around or during social events. Respondents answering particular questions about their activity choose the level of its intensity disregarding the number of days in a typical week or the number of minutes on a typical day. There are two types to choose from: vigorous-intensity activities (i.e. the ones requiring

\section{Przebieg prac adaptacyjnych kwestionariusza GPAQ do polskich warunków}

Celem tego procesu było uzyskanie polskiej wersji językowej angielskojęzycznego kwestionariusza GPAQ. Przystosowanie narzędzia miało na celu zgodnie z założeniami WHO stworzyć kwestionariusz, który nie będzie dosłownie tłumaczony, lecz w sposób zrozumiały i naturalny dla Polaków. Tekst źródłowy przetłumaczono na język polski, a następnie dokonano tłumaczenia zwrotnego w następujących krokach:

1. Tłumaczenie $z$ języka angielskiego na jezzk polski przez osobę, której językiem ojczystym jest język polski i posiada bardzo dobrą znajomość języka angielskiego, w tym znajomość terminologii obszaru objętego tłumaczeniem, kładącą nacisk na tłumaczenia pojęciowe, a nie dosłowne.

2. Dwujęzyczny panel ekspertów (w języku angielskim i języku polskim). Celem tego etapu było znalezienie i poprawienie nieodpowiednich wyrażeń/koncepcji tłumaczenia. W wyniku tego procesu powstała przetłumaczona wersja kwestionariusza.

3. Tłumaczenie zwrotne. Kwestionariusz został przetłumaczony z powrotem na język angielski przez niezależnego tłumacza, którego językiem ojczystym jest język angielski i posiada bardzo dobra znajomość języka polskiego. Rozbieżności tłumaczeniowe zostały omówione przez dwujęzyczny panel ekspertów.

4. Wstepne testy. Po zakończonym procesie tłumaczenia kwestionariusz został skierowany techniką wywiadu bezpośredniego do grupy 10 osób w celu sprawdzenia, czy zastosowane $\mathrm{w}$ kwestionariuszu przetłumaczone terminy i wyrażenia są zrozumiałe dla przedstawicieli docelowej grupy badawczej.

\section{Opis kwestionariusza}

Kwestionariusz globalnej aktywności GPAQ składa się z czterech niezależnych części zawierających 16 pytań. Pytania dotyczą czasu poświęconego na aktywność fizyczną trwającą minimum 10 minut bez przerwy w ciągu typowego dla respondenta tygodnia. Pierwsze trzy części kwestionariusza obejmują aktywność w pracy, aktywność w przemieszczeniu się oraz aktywność rekreacyjną. W czwartej części zadane jest jedno pytanie o czas spędzony na siedzeniu lub odpoczynku w pozycji leżącej w pracy, w domu, w trakcie przemieszczania się, lub przy okazji spotkań towarzyskich. Respondenci odpowiadając na poszczególne pytania dotyczące ich aktywności poza ilością dni w typowym tygodniu oraz ilością minut w typowym dniu wybierają poziom intensywności. Do wyboru są dwa rodzaje: czynności o dużej intensywności (czyli czynności wymagające dużego wy- 
high physical effort, causing a significant increase in breathing or heart rate) and moderate-intensity activities (the ones requiring moderate physical effort, resulting in small increase of breathing or heart rate). The first part (questions 1-6) concerns work-related physical activity, agricultural activities, household chores, social work, education and any other paid or unpaid work undertaken at home or outside. This part of the question concerns two intensity levels: vigorous and moderate. The second part (questions 7-9) relates to the domain of transportation. In this part, one should disregard the time devoted to physical activity at work, as this information was included in the first tested domain. This part involves transportation-related activities in a typical week, e.g. travel to and from work, while shopping, going to church, etc. Further, the questions of this domain apply only to walking and cycling for at least 10 minutes continuously. In this part, the intensity levels of effort are not considered. The third part (questions 10-15) concerns activities undertaken in leisure time involving recreational, fitness and sports purposes, excluding at the same time the activities mentioned in the two previous parts. In this domain, as in the case of the first one, there are two intensity levels to choose form (vigorous intensity and moderate intensity). Part four (question 16) refers to sedentary behaviour. In this part, one should sum up the average amount of time during the day spent sitting or reclining, both at work, home or while to and from places. Sitting behind a desk, on a bench, sitting with friends, driving a car, bus, train, reading, eating meals, watching TV, etc. should also be taken into account

\section{Calculating and clearing the data on physical activity}

When preparing the data for calculations, all cases exceeding 16 hours of activity in one day or exceeding 7 days a week should be removed, as indicated by the guidelines of the GPAQ Guide. The following MET metabolic equivalent values are used to calculate the total energy expenditure of a person using the GPAQ questionnaire data:

Table 1. Metabolic Equivalent of Task - MET

Tabela 1. Równoważnik metaboliczny - MET

\begin{tabular}{|c|c|c|}
\hline Domain/ Domena & Intensity level/ Poziom intensywności & MET value/ Wartość MET \\
\hline Work/ Praca & $\begin{array}{c}\bullet \text { Moderate/ Umiarkowany } \\
\bullet \text { Vigorous/ Duży } \\
\end{array}$ & $\begin{array}{r}4.0 \\
8.0 \\
\end{array}$ \\
\hline $\begin{array}{c}\text { Transportation/ } \\
\text { Przemieszczanie się }\end{array}$ & $\begin{array}{l}\text { - Cycling and walking/ } \\
\text { Jazda na rowerze i chodzenie }\end{array}$ & 4.0 \\
\hline Recreation/ Rekreacja & $\begin{array}{l}\text { - Moderate/ Umiarkowany } \\
\text { • Vigorous/ Duży }\end{array}$ & $\begin{array}{l}4.0 \\
8.0\end{array}$ \\
\hline
\end{tabular}

siłku fizycznego, powodujące znaczne przyśpieszenie oddechu i bicia serca) oraz czynności o umiarkowanej intensywności (czynności wymagające umiarkowanego wysiłku fizycznego, powodujące małe przyśpieszenia oddechu i bicia serca). Pierwsza część (pytania 1-6) dotyczy aktywności fizycznej w trakcie pracy, w rolnictwie, w obowiązkach domowych, pracach społecznych, nauki i każdej innej płatnej lub nieodpłatnej pracy podejmowanej $\mathrm{w}$ domu lub poza domem. $\mathrm{W}$ tej części pytania dotyczą dwóch poziomów intensywności: dużej oraz umiarkowanej. Druga część (pytania 7-9) dotyczy aktywności w domenie przemieszczania się. W tej części należy pominąć czas poświęcony na aktywność fizyczną w pracy, o której była mowa w pierwszej domenie. Ta część obejmuje czynności związane pracy, na zakupy, do kościoła itp. Pytania tej domeny dotyczą wyłącznie chodzenia oraz jazdy rowerem przez co najmniej 10 minut bez przerwy. W tej części nie są rozpatrywane poziomy intensywności wysiłków. Trzecia część (pytania 10-15) dotyczy aktywności podejmowanych w czasie wolnym dla celów rekreacyjnych, fitnessowych, sportowych, przy wykluczeniu czynności, o których była mowa w dwóch wcześniejszych częściach. W tej domenie, podobnie jak w przypadku części pierwszej, pytania dotyczą dwóch poziomów intensywności (dużej intensywności oraz intensywności umiarkowanej). Część czwarta (pytanie 16) dotyczy czasu spędzonego siedząc. W tej części należy zsumować średnią ilość czasu w ciągu dnia na siedzenie lub odpoczynek w pozycji leżącej, w pracy, w domu oraz w trakcie przemieszczania się. Należy uwzględnić siedzenie za biurkiem, w ławce, siedzenie ze znajomymi, przyjaciółmi, jazdę samochodem, autobusem, pociągiem, czytanie, jedzenie posiłków, oglądanie telewizji itp.

\section{Obliczenia i czyszczenie danych dotyczących ak- tywności fizycznej}

W trakcie przygotowania danych do obliczeń należy, zgodnie z wytycznymi Przewodnika GPAQ, usunąć przypadki przekraczające 16 godzin aktywności w przeciągu jednego dnia lub przekraczające 7 dni w tygodniu. Do obliczenia całkowitego wydatku energetycznego danej osoby za pomocą danych kwestionariusza GPAQ stosuje się następujące wartości równoważnika metabolicznego MET: $\mathrm{z}$ przemieszczaniem się $\mathrm{w}$ typowym tygodniu np. do 
MET is commonly used to express the intensity of physical activity. It is the ratio between a person's metabolic rate during a specific effort to a particular reference in the metabolic index at rest. One MET is defined as energy expenditure during quiet sitting, and it is equivalent to the consumption of calories 1 $\mathrm{kcal}$ / kg / hour (a value assumed for a statistical adult - mean age 40 , mean body weight $70 \mathrm{~kg}$ ).

\section{WHO recommendations for a pro-health dose of physical activity}

According to the recommendations of the WHO and taking into account all domains under consideration (activity at work, traveling to and from places and leisure time activity time), adults should demonstrate at least:

- 150 minutes of moderate-intensity physical activity or

- 75 minutes of vigorous-intensity physical activity or

- the sum of physical activity of moderate- and vigorous-intensity activity, reaching at least 600 MET minutes.

\section{Conclusions}

The former experience of the authors researching physical activity shows that the best form of conducting studies is an interview carried out by very well trained interviewers. This is also recommended in the case of the Polish version of the GPAQ. Special instruction is also needed so that attention is drawn to understanding the questions. One should verify the responses regarding the amount of time in each domain exceeding four hours a day, except for sitting. Considering the fact that physical activity is seasonal and specific to residents of different countries, the most favourable time for conducting research in Poland is October and November, as well as March, as indicated in the Polish version of the IPAQ [4].
MET jest powszechnie stosowany do wyrażenia intensywności aktywności fizycznej. Stanowi on stosunek pomiędzy wskaźnikiem metabolicznym danej osoby podczas wysiłku, a wskaźnikiem metabolicznym w spoczynku. Jeden MET definiuje się jako wydatek energetyczny podczas spokojnego siedzenia i jest on równoważny zużyciu kalorii $1 \mathrm{kcal} / \mathrm{kg} /$ godzinę (wartość przyjmowana dla statystycznej osoby dorosłej - średni wiek 40 lat, średnia masa ciała $70 \mathrm{~kg}$ ).

\section{Zalecenia WHO dotyczące prozdrowotnej dawki aktywności fizycznej}

Według zaleceń WHO w ciągu jednego tygodnia osoby dorosłe powinny wykazać się, przy uwzględnieniu wszystkich rozpatrywanych domen (aktywności w pracy, podczas przemieszczania się i w czasie wolnym), przynajmniej:

- 150 minutami aktywności fizycznej o umiarkowanej intensywności lub

- 75 minutami aktywności fizycznej o dużej intensywności lub

- sumą aktywność fizycznej o umiarkowanej i dużej intensywności aktywności, uzyskując przynajmniej 600 MET minut.

\section{Podsumowanie}

Dotychczasowe doświadczenia autorów badań nad aktywnością fizyczną pokazują, że najlepszą formą ich przeprowadzenia powinien być wywiad z udziałem bardzo dobrze przeszkolonych ankieterów. Takie zalecenia przedkładamy także dla polskiej wersji GPAQ. Potrzebna jest także specjalna instrukcja, w której zwraca się uwagę na zrozumienie pytań. Należy zweryfikować odpowiedzi dotyczące ilości czasu w każdej z domen, poza siedzeniem, przekraczające cztery godziny dziennie. Biorąc pod uwagę, że aktywność fizyczna ma charakter sezonowy, który jest specyficzny dla mieszkańców różnych państw, termin $\mathrm{w}$ miesiącach październik i listopad oraz marzec jest najbardziej korzystny do badań w Polsce idąc za argumentacją polskiej wersji IPAQ [4].

\section{References / Literatura:}

1. Biernat E, Piątkowska M. Stay active for life - physical activity across life stages. Clinical Interventions in Aging. 2018; 13: 1341-1352. http://dx.doi.org/10.2147/CIA.S167131

2. Varo JJ, Martínez-González M, de Irala-Estévez J, Kearney J, Gibney M, Martínez JA. Distribution and determinants of sedentary lifestyles in the European Union. Int J Epidemiol. 2003; 32: 138-46.

https://doi.org/10.1093/ije/dyg116

3. Craig CL, Marshall AL, Sjöström M, Bauman AE, Booth ML, Ainsworth BE, et al. International physical activity questionnaire: 12-country reliability and validity. Med. Sci. Sports Exer. 2003; 35: 1381-1395. https://doi.org/10.1249/01.MSS.0000078924.61453.FB

4. World Health Organization. Global health risks: mortality and burden of disease attributable to selected major risks. Geneva: WHO Press; 2009. 
5. Biernat E, Stupnicki R, Gajewski AK. [International Physical Activity Questionnaire (IPAQ) - Polish version]. Wych Fiz Sport. 2007; 51: 47-54 (in Polish).

6. Bull FC, Maslin TS, Armstrong T. Global physical activity questionnaire (GPAQ): nine country reliability and validity study. J Phys Act Health. 2009; 6: 790-804. https://doi.org/10.1123/jpah.6.6.790

7. Armstrong N, Welsman JR. The physical activity patterns of European youth with reference to methods of assessment. Sports Med. 2006; 36(12): 1067-108. https://doi.org/10.2165/00007256-200636120-00005

8. Wallmann-Sperlich B, Bucksch J, Hansen S, Schantz P, Froboese I. Sitting time in Germany: an analysis of socio-demographic and environmental correlates. BMC Public Health. 2013; 13: 196. https://doi.org/10.1186/1471-2458-13-196

9. Hamrik Z, Sigmundová D, Kalman M, Pavelka J, Sigmund E. Physical activity and sedentary behaviour in Czech adults: results from the GPAQ study. Eur J Sport Sci. 2014; 14: 193-8. https://doi.org/10.1080/17461391.2013.822565

10. Biernat E. [International Physical Activity Questionnaire - Polish long version]. Medycyna Sportowa. 2013; 29(1): 1-15 (in Polish).

11. Booth ML. Assessment of physical activity: an international perspective. Res Quart Exerc Sport. 2000; 71: 114-20. https://doi.org/10.1080/02701367.2000.11082794 


\title{
Appendix / Załącznik
}

\author{
Globalny Kwestionariusz Aktywności Fizycznej \\ Wielostopniowy system monitorowania czynników ryzyka \\ przewlekłych chorób niezakaźnych
}

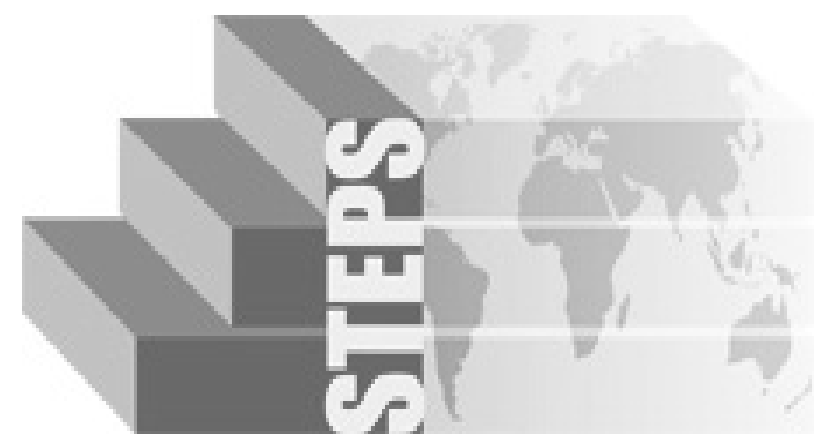

Surveillance and Population-Based Prevention

Prevention of Noncommunicable Diseases Department

World Health Organization

20 Avenue Appia, 1211 Geneva 27, Switzerland

For further information: www.who.int/chp/steps

\begin{tabular}{|c|c|c|c|c|}
\hline \multicolumn{5}{|c|}{$\begin{array}{ll}\text { Aktywność Fizyczna } \\
\end{array}$} \\
\hline \multicolumn{5}{|c|}{$\begin{array}{l}\text { Chcemy spytać Pana/nią o czas spędzany na różnego typu fizycznej aktywności w ciągu typowego tygodnia. Prosimy, aby } \\
\text { odpowiedział/a Pan/i, nawet jeśli nie uważa się Pan/i za osobę aktywną fizycznie. } \\
\text { Najpierw proszę pomyśleć o czasie poświęconym na pracę. Proszę pomyśleć o pracy jako czynnościach, które ma Pan/i do } \\
\text { wykonania, pracując płatnie lub nieodpłatnie - praca zawodowa, studia/nauka, obowiązki domowe, prace w rolnictwie, } \\
\text { ogrodzie oraz wszystkie inne prace podejmowane w domu lub poza domem. } \\
\text { Odpowiadając na poniższe pytania, proszę przyjąć, że: „czynności o dużej intensywności” to czynności wymagające duże- } \\
\text { go wysiłku fizycznego, powodujące znaczne przyśpieszenie oddechu i bicia serca; „czynności o umiarkowanej intensyw- } \\
\text { ności” to czynności wymagające umiarkowanego fizycznego wysiłku, powodujące małe przyśpieszenie oddechu i bicia } \\
\text { serca. }\end{array}$} \\
\hline \multicolumn{2}{|r|}{$\begin{array}{c}\text { Pytania } \\
\end{array}$} & \multicolumn{2}{|c|}{ Odpowiedź } & Kod \\
\hline \multicolumn{5}{|c|}{$\begin{array}{ll} & \text { Aktywność w pracy } \\
\end{array}$} \\
\hline \multirow{2}{*}{1} & \multirow{2}{*}{$\begin{array}{l}\text { Czy Pana/i praca wymaga czynności o dużej intensywno- } \\
\text { ści, powodującej znaczne przyśpieszenie oddechu i bicia } \\
\text { serca [jak np. noszenie lub dźwiganie ciężkich ładunków, } \\
\text { kopanie lub roboty budowlane] przez co najmniej } 10 \text { minut } \\
\text { bez przerwy? [PODAJ PRZYKŁADY] (UŻYJ KART INFOR- } \\
\text { MACYJNYCH) }\end{array}$} & Tak & 1 & \multirow{2}{*}{$\mathrm{P} 1$} \\
\hline & & Nie & 2 Jeśli nie, przejdź do P4 & \\
\hline 2 & $\begin{array}{l}\text { Wilu dniach, w typowym tygodniu wykonuje Pan/i czyn- } \\
\text { ności o dużej intensywności, jako część swojej pracy? }\end{array}$ & Liczba dni & $\left.L_{-}\right\lrcorner$ & $\mathrm{P} 2$ \\
\hline 3 & $\begin{array}{l}\text { Ile czasu w typowym dniu pracy spędza Pan/i na wyko- } \\
\text { nywaniu czynności o dużej intensywności? }\end{array}$ & Godziny : minuty & 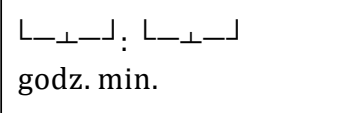 & $\begin{array}{l}\text { P3 } \\
(\mathrm{a}-\mathrm{b})\end{array}$ \\
\hline \multirow{2}{*}{4} & \multirow{2}{*}{$\begin{array}{l}\text { Czy Pana/i praca wymaga czynności o umiarkowanej } \\
\text { intensywności, powodujących małe przyśpieszenie od- } \\
\text { dechu i bicia serca, takich jak szybki spacer [lub przeno- } \\
\text { szenie lekkich ładunków] przez co najmniej } 10 \text { minut bez } \\
\text { przerwy? }\end{array}$} & Tak & 1 & \multirow[b]{2}{*}{ P4 } \\
\hline & & Nie & 2 Jeśli nie, przejdź do P 7 & \\
\hline
\end{tabular}




\begin{tabular}{|c|c|c|c|c|}
\hline 5 & $\begin{array}{l}\text { W typowym tygodniu, w ilu dniach wykonuje Pan/i czyn- } \\
\text { ności o umiarkowanej intensywności, jako część swojej } \\
\text { pracy? }\end{array}$ & Liczba dni & $L_{-}$ & P5 \\
\hline 6 & $\begin{array}{l}\text { W typowym dniu pracy, ile czasu spędza Pan/i na wyko- } \\
\text { nywaniu czynności o umiarkowanej intensywności? }\end{array}$ & Godziny : minuty & $\begin{array}{l}\mathrm{L}-\perp ー 」: \mathrm{L} \_\perp-」 \\
\text { godz.min. }\end{array}$ & $\begin{array}{l}\text { P6 } \\
(\mathrm{a}-\mathrm{b})\end{array}$ \\
\hline \multicolumn{5}{|c|}{ Przemieszczanie się } \\
\hline \multicolumn{5}{|c|}{$\begin{array}{l}\text { Kolejne pytania nie dotyczą wysiłków fizycznych wykonywanych w pracy, o którą już był/a Pan/i pytany/a poprzednio. } \\
\text { Obecnie, chciałbym spytać, w jaki sposób, zazwyczaj, przemieszcza się Pan/i np. do pracy, na zakupy, do marketu, do ko- } \\
\text { ścioła. }\end{array}$} \\
\hline \multirow{2}{*}{7} & \multirow{2}{*}{$\begin{array}{l}\text { Czy w typowym tygodniu w celu przemieszczania się } \\
\text { chodzi Pan/i lub jeździ rowerem przez co najmniej } 10 \text { mi- } \\
\text { nut bez przerwy? }\end{array}$} & Tak & 1 & \multirow{2}{*}{ P7 } \\
\hline & & Nie & 2 Jeśli nie, przejdź do P 10 & \\
\hline 8 & $\begin{array}{l}\text { Ile dni w typowym tygodniu, chodzi Pan/i lub jeździ ro- } \\
\text { werem przez co najmniej } 10 \text { minut bez przerwy? }\end{array}$ & Liczba dni & L_」 & P8 \\
\hline 9 & $\begin{array}{l}\text { Ile czasu w typowym dniu chodzi Pan/i lub jeździ rowe- } \\
\text { rem przez co najmniej } 10 \text { minut bez przerwy? }\end{array}$ & Godziny : minuty & 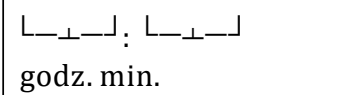 & $\begin{array}{c}\text { P9 } \\
(a-b)\end{array}$ \\
\hline \multicolumn{5}{|c|}{ Aktywność rekreacyjna } \\
\hline \multicolumn{5}{|c|}{$\begin{array}{l}\text { W kolejnych pytaniach proszę nie brać pod uwagę wysiłków fizycznych wykonywanych w pracy i w trakcie przemieszcza- } \\
\text { nia się, o które był/a Pan/i już pytany/a. Obecnie, chciałbym spytać o Pana/i aktywność podejmowaną w czasie wolnym } \\
\text { dla celów rekreacyjnych, fitnessowych, sportowych. }\end{array}$} \\
\hline \multirow{2}{*}{10} & $\begin{array}{l}\text { Czy uprawia Pan/i sport, fitness lub podejmuje aktyw- } \\
\text { ność rekreacyjną o dużej intensywności, powodujące }\end{array}$ & Tak & 1 & \multirow{2}{*}{ P10 } \\
\hline & $\begin{array}{l}\text { znaczne przyśsieszenie oddechu i bicia serca, takie jak } \\
\text { bieganie, gra w piłkę nożną itp. przez co najmniej } 10 \mathrm{mi}- \\
\text { nut bez przerwy? }\end{array}$ & Nie & 2 Jeśli nie, przejdź do P 13 & \\
\hline 11 & $\begin{array}{l}\text { W ilu dniach, w typowym tygodniu uprawia Pan/i sport, } \\
\text { fitness lub podejmuje aktywność rekreacyjną o dużej in- } \\
\text { tensywności? }\end{array}$ & Liczba dni & L_」 & P11 \\
\hline 12 & $\begin{array}{l}\text { Ile czasu w typowym dniu spędza Pan/i na uprawianiu } \\
\text { sportu, fitness lub aktywności rekreacyjnej o dużej in- } \\
\text { tensywności? }\end{array}$ & Godziny : minuty & $\begin{array}{l}\left.\mathrm{L}_{\perp}-\right\lrcorner: \mathrm{L} \_\perp-」 \\
\text { godz. min. }\end{array}$ & $\begin{array}{l}\text { P12 } \\
(a-b)\end{array}$ \\
\hline \multirow{2}{*}{13} & \multirow{2}{*}{$\begin{array}{l}\text { Czy uprawia Pan/i sport, fitness lub podejmuje aktyw- } \\
\text { ność rekreacyjną o umiarkowanej intensywności, powo- } \\
\text { dujące małe przyśpieszenie oddechu i bicia serca, takie } \\
\text { jak [jazda rowerem, pływanie, siatkówka] przez co naj- } \\
\text { mniej } 10 \text { minut bez przerwy? }\end{array}$} & Tak & 1 & \multirow{2}{*}{$\mathrm{P} 13$} \\
\hline & & Nie & 2 Jeśli nie, przejdź do P16 & \\
\hline 14 & $\begin{array}{l}\text { W ilu dniach, w typowym tygodniu uprawia Pan/i sport, } \\
\text { fitness lub podejmuje aktywność rekreacyjną o umiarko- } \\
\text { wanej intensywności? }\end{array}$ & Liczba dni & L_」 & P14 \\
\hline 15 & $\begin{array}{l}\text { Ile czasu w typowym dniu spędza Pan/i na uprawianiu } \\
\text { sportu, fitness lub aktywności rekreacyjnej o umiarko- } \\
\text { wanej intensywności? }\end{array}$ & Godziny : minuty & 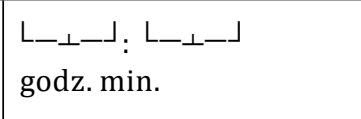 & $\begin{array}{l}\text { P15 } \\
(a-b)\end{array}$ \\
\hline \multicolumn{5}{|c|}{ Aktywność sedentarna } \\
\hline \multicolumn{5}{|c|}{$\begin{array}{l}\text { Poniższe pytanie dotyczy siedzenia lub odpoczynku w pozycji leżącej w pracy, w domu, w trakcie przemieszczania się tam } \\
\text { i z powrotem, lub przy okazji spotkań towarzyskich [siedzenie za biurkiem, siedzenie ze znajomymi, przyjaciółmi, jazdę sa- } \\
\text { mochodem, autobusem, pociagiem, czytanie, grę w karty, oglądanie telewizji], lecz nie wliczając czasu poświęconego na sen. }\end{array}$} \\
\hline 16 & $\begin{array}{l}\text { Ile czasu w typowym dniu spędza Pan/i na siedzeniu lub } \\
\text { odpoczynku w pozycji leżącej? }\end{array}$ & Godziny : minuty & $\begin{array}{l}\mathrm{L} ー \perp ー\lrcorner: \mathrm{L}-\perp ー 」 \\
\text { godz.min. }\end{array}$ & $\begin{array}{l}\text { P16 } \\
(a-b)\end{array}$ \\
\hline
\end{tabular}

